\title{
PEMANFAATAN TEPUNG MANURE HASIL DEGRADASI LARVA LALAT HITAM (Hermetia illucens L.) TERHADAP BERAT TELUR, BERAT KUNING TELUR DAN MASSA TELUR AYAM KAMPUNG
}

\author{
Wahyu Tumiran, C. L. K. Sarajar, F. J. Nangoy* dan J. T. Laihad
}

\author{
Fakultas Peternakan Universitas Sam Ratulangi Manado
}

\begin{abstract}
ABSTRAK
Ayam Kampung telah banyak dipelihara oleh peternak-peternak maupun masyarakat umum sebagai usaha untuk pemanfaatan pekarangan, pemenuhan gizi keluarga serta meningkatkan pendapatan. Salah satu fungsi dari ayam kampung petelur adalah sebagai penghasil telur. Telur ayam kampung sudah sering dikonsumsi dan digemari masyarakat Indonesia. Kualitas telur ayam kampung perlu ditingkatkan dengan pemberian pakan dengan gizi seimbang. Tepung Manure Hasil Degradasi Larva dari Hermetia illucens $L$. merupakan salah satu alternatif pakan sebagai sumber protein. Tepung MHD mengandung protein 51,15\%. Karena mengandung zat-zat makanan yang dapat memenuhi kebutuhan unggas. Hal ini tentunya akan berdampak positif apabila pemanfaatan manure hasil degradasi larva lalat hitam dapat digunakan sebagai pakan ternak ayam. Karena kandungan nutrisi dalam pakan juga mempengaruhi produksi dan kualitas telur. Materi yang digunakan adalah ayam kampung fase layer umur 56 minggu sebanyak 40 ekor. Kandang yang digunakan adalah kandang baterai dengan ukuran kandang 50 × 50 x 75, dilengkapi tempat makan dan minum. Penelitian menggunakan rancangan acak lengkap (RAL) yang terdiri dari 4 perlakuan dan 5 ulangan, sebagai perlakuan adalah tepung manure hasil degradasi larva lalat hitam
\end{abstract}

\footnotetext{
*Korepondensi (corresponding autor)

Email: fredynangoy@yahoo.com
}

(hermetia illucens) sebagai berikut: R0 = Tepung MHD 0\%, R1 = Tepung MHD 5\%, R2 = Tepung MHD 10\% dan R3 = Tepung MHD 15\%. Dari hasil penelitian menunjukkan bahwa pemanfaatan tepung manure hasil degradasi larva lalat hitam (Hermetia Illucens L.) menunjukkan bahwa perlakuan tidak memberikan pengaruh yang nyata $(\mathrm{P}>0,05)$ terhadap berat telur, berat kuning telur dan massa telur ayam kampung. Sehingga dapat disimpulkan pemanfaatan tepung manure hasil degradasi larva lalat hitam (Hermetia Illucens L.) dengan level sampai $15 \%$ pada ayam kampung menghasilkan berat telur, berat kuning telur dan massa telur yang sama pada ayam kampung. MHD dapat digunakan dalam ransum ayam kampung sebanyak $15 \%$.

Kata Kunci: Manure, Larva, Telur.

\section{ABSTRACT}

UTILIZATION OF MANURE DEGRADATED FLOUR BY BLACK FLIES (Hermetia illucens L) ON EGG WEIGHT, EGG YELLOW YOLK AND EGG MASS OF NATIVE CHICKEN. Native Chicken has been maintained by farmers as an effort to utilize the yard, to fulfill the family nutrition and to increase income. One of the functions of laying chicken is as an egg producer. Chicken eggs are often consumed and loved by the people of Indonesia. The quality of chicken eggs needs to be improved by providing 
balanced feed and nutrition. Manure Flour degradated by larva of $\mathrm{H}$. illucens is one of alternative feed as a source of protein. MHD flour contains $51.15 \%$ protein. For this reasons, Because it can meet the needs of poultry. This will have a positive impact if the utilization of manure degradated by black flies larvae can be used as the substitution of some concentrates. Forty native chickens females aged 56 weeks had been used. Baterry system cages of $50 \times 50 \times 75 \mathrm{~cm}$ with an eat and drink. A randomized complete design (RAL) with 4 treatment and 5 replications was used as design methods. Treatmens was the following level of manure flour degradated by black flies larvae: R0 $=0 \%$ flour MHD: $\mathrm{R} 1=5 \%$ flour $\mathrm{MHD}: \mathrm{R} 2=10 \%$ flour MHD: R3 $=15 \%$ flour MHD. Variables measured were egg weight, egg yolk weight and egg mass. The results showed that the there was no significant difference $(\mathrm{P}>$ $0,05)$ between treatmentsand egg weight, yolk weight and egg mass. Based on the result of data analysis and discussion, it can be concluded that the utilization of manure flour degradated by black flies larvae up to $15 \%$ will not give different results in egg weight, egg yolk and egg mass.

Keywords: Manure, Larva, Egg.

\section{PENDAHULUAN}

Ayam kampung merupakan ayam lokal yang menyebar di seluruh kepulauan Indonesia yang sering dipelihara peternak dan masyarakat pedesaan sebagai usaha untuk pemanfaatan pekarangan, pemenuhan gizi dan peningkatan pendapatan. Ternak unggas khususnya ayam kampung merupakan salah satu alternatif yang diharapkan dapat menyediakan protein hewani bagi masyarakat guna memenuhi gizi masyarakat berupa telur.

Telur ayam kampung masih merupakan potensi yang besar terutama untuk daerah pedesaan, sementara konsumen di daerah perkotaan beranggapan bahwa telur ayam kampung lebih enak dibandingkan telur ayam ras (Umar et al., 2000). Kualitas telur adalah istilah umum untuk menentukan kualitas eksternal dan internal. Salah satu faktor yang dapat mempengaruhi kualitas telur ayam kampung adalah pakan yang diberikan pada ternak tersebut.

Manure adalah feses unggas dengan campuran urin, dan merupakan pakan utama dari beragam serangga di alam, termasuk juga larva $H$. illucens $L$ (lalat hitam). Keberadaan serangga di alam ini memang sudah diciptakan sedemikian rupa sehingga dapat berperan dalam proses siklus alami penyiapan nutrisi dari manure dan sudah tentu dapat menghasilkan sumber pakan untuk ternak. Serangga dapat membiodegradasi limbah protein dan nutrisi lainnya pada manure menjadi suatu biomasa yang kaya akan protein sehingga bisa dijadikan pakan ternak alternatif. Manure yang dibiodegradasi menggunakan lalat rumah tersebut menghasilkan penurunan akumulasi manure, manure menjadi berbentuk granul, dan pengurangan bau manure akibat penurunan nitrogen mencapai 20\% (Tomiczek, 2006). 
Tepung Manure hasil degradasi larva dari $H$. illucens $L$ merupakan salah satu alternatif pakan sebagai sumber protein. Tepung MHD mengandung protein 51,15\% (Manangkot, 2014). Kandungan nutrien yang tinggi dari larva Hermetia illucens L. membuatnya ideal sebagai pakan hewan (Wangko, 2014)

Bertolak dari pemikiran tersebut diatas maka telah dilakukan penelitian dengan tujuan untuk mengetahui pemanfaatan manure hasil degradasi larva lalat hitam (Hermetia Illucens L.) terhadap berat telur, berat kuning telur dan massa telur ayam kampung.

\section{MATERI DAN METODE PENELITIAN}

Materi yang digunakan dalam penelitian ini adalah ayam kampung fase layer berumur 56 minggu sebanyak 40 ekor. Kandang yang digunakan dalam penelitian ini adalah kandang baterai. Bahan pakan yang digunakan dalam penelitian ini adalah jagung, konsentrat, dan tepung MHD. Metode penelitian yang digunakan adalah rancangan acak lengkap dengan 4 perlakuan dan 5 ulangan.

Berat telur ditimbang dengan menggunakan timbangan elektrik dan berat kuning telur ditimbang dan diambil datanya setiap hari rabu minggu berjalan dengan cara memisahkan kuning telur dan putih telur menggunakan sendok dan kuning telur ditempatkan di cawan petri untuk kemudian ditimbang menggunakan timbangan elektrik.

Komposisi bahan pakan penyusun ransum, ransum penelitian dan zat-zat makanan ransum penelitian dapat dilihat pada Tabel 1, 2 dan 3.

Variabel yang diamati didalam penelitian ini adalah :

1. Berat Telur merupakan perbandingan antara jumlah berat telur yang dihasilkan (g) dengan jumlah telur yang dihasilkan (butir) (North, 1984), dengan rumus :

$\mathrm{BT}=\frac{\text { Jumlah berat telur yang dihasilkan }(\mathrm{g})}{\text { Jumlah telur yang dihasilkan (butir) }}$

2. Berat Kuning Telur (g)

Berat kuning telur diukur dengan cara menimbang setiap kuning telur (North, 1984). Pengukurannya dilakukan dengan melakukan penimbangan berat kuning telur (g) setelah dipisahkan dari putih telur.

\section{Massa Telur}

Massa telur merupakan hasil kali antara berat telur dengan HDP.

Satuannya adalah gram/ekor/hari. Penentuan massa telur Olgun et al. (2009)

Sebagai berikut.

$\mathrm{EM}=\frac{\text { HDP X BT }}{\text { PP }}$

Keterangan: 


$\begin{array}{llll}\text { EM } & : \text { Egg Mass (g/ekor/hari) } & \text { BT } & : \text { Berat Telur (g/ekor/hari) } \\ \text { HDP } & : \text { Hen Day Production (\%) } & \text { PP } & : \text { Periode Penelitian (hari) }\end{array}$

Tabel 1. Komposisi zat gizi Tepung MHD

\begin{tabular}{lc}
\hline Zat Gizi & Tepung MHD \\
\hline Protein & 51,15 \\
Lemak & 2,06 \\
Serat Kasar & 2,75 \\
Kalsium & 9,84 \\
Phospor & 3,20 \\
ME (Kkal) & 2940 \\
\hline
\end{tabular}

Ket : Hasil Analisa Manangkot (2014)

Tabel 2. Komposisi Ransum Percobaan

\begin{tabular}{lllll}
\hline \multirow{2}{*}{ Bahan Makanan } & \multicolumn{5}{c}{ Jumlah } \\
\cline { 2 - 5 } & R0 & R1 & R2 & R3 \\
\hline Jagung (\%) & 60 & 60 & 60 & 60 \\
Konsentrat (\%) & 40 & 35 & 30 & 25 \\
Tepung MHD (\%) & 0 & 5 & 10 & 15 \\
\hline Total & 100 & 100 & 100 & 100 \\
\hline
\end{tabular}

Tabel 3. Komposisi zat-zat makanan ransum percobaan

\begin{tabular}{lcccc}
\hline \multicolumn{1}{c}{ Kandungan zat makanan } & R0 & R1 & R2 & R3 \\
\hline Protein (\%) & 17,16 & 18,16 & 19,26 & 20,07 \\
Serat Kasar (\%) & 4,00 & 3,75 & 3,50 & 3,26 \\
Lemak (\%) & 3,14 & 3,18 & 3,22 & 3,25 \\
Ca (Kalsium) (\%) & 4,81 & 4,70 & 4,60 & 4,50 \\
P (Fosfor) (\%) & 0,78 & 0,87 & 0,95 & 1,03 \\
Energi (EM) Kkal/kg & 2410 & 2509 & 2607 & 2705 \\
\hline
\end{tabular}

Ket : Hasil Perhitungan komposisi zat-zat makanan.

\section{Analisis Data}


Data yang diperoleh diihitung secara statistik dengan menggunakan analisis ragam menggunakan rancangan acak lengkap (RAL) (Steel and Torrie, 1994).

\section{HASIL DAN PEMBAHASAN}

\section{Pengaruh Perlakuan Terhadap Berat Telur}

Data hasil penelitian menunjukkan bahwa penggunaan tepung manure hasil degradasi larva lalat hitam (Hermetia illucens L.) dalam ransum ayam kampung, tidak memberikan pengaruh yang nyata $(\mathrm{P}>0,05)$ terhadap berat telur. Dengan pengertian bahwa penggunaan tepung manure hasil degradasi larva lalat hitam (Hermetia illucens L.) dengan level 5\%, $10 \%, 15 \%$ dalam ransum ayam kampung, tidak menyebabkan perbedaan terhadap berat telur. Hasil penelitian menunjukkan rataan berat telur untuk masing-masing perlakuan berkisar antara 51,70-53,33 g. Hasil penelitian ini berada diatas standar yang dikemukakan oleh Sarwono (1995) bahwa berat telur ayam kampung berkisar 35,00-45,00 g. Berat telur dipengaruhi oleh faktor-faktor yaitu genetik, tahap kedewasaan, umur, zat-zat makanan dalam pakan. Analisis ragam berat telur menunjukkan bahwa perlakuan tidak memberikan pengaruh yang nyata $(\mathrm{P}>0,05)$ terhadap berat telur. Hal ini disebabkan karena kandungan zat-zat makanan pada ransum penelitian terutama protein dan energi seimbang, sehingga pengaruh penggunaan tepung manure hasil degradasi larva lalat hitam (Hermetia illucens L.) level 5-15\% tidak memberikan pengaruh yang nyata terhadap berat telur.

Menurut Latifah (2007), besar kecilnya ukuran telur unggas sangat dipengaruhi oleh kandungan protein dan asam-asam amino esensial dalam pakan. Kandungan zat-zat makanan dalam ransum penelitian ini, antara lain protein dan energi seimbang. Artinya, kandungan zat-zat makanan sudah terpenuhi sesuai kebutuhan ayam kampung.

\section{Pengaruh Perlakuan Terhadap Berat Kuning Telur}

Data hasil penelitian menunjukkan bahwa penggunaan tepung manure hasil degradasi larva lalat hitam (Hermetia Illucens L.) pada ransum ayam kampung menunjukkan pengaruh yang tidak berbeda nyata terhadap berat kuning telur ayam kampung. Rataan berat kuning telur untuk masing-masing perlakuan berkisar antara 16,19-17,90 g. Hasil penelitian ini masih berada diatas standar yang dikemukakan oleh Hartono (2014) yaitu 12,83-16,00 g. 
Tabel. 4. Pengaruh perlakuan terhadap berat telur, berat kuning telur dan massa telur

\begin{tabular}{cccc}
\hline \multirow{2}{*}{ Perlakuan } & \multicolumn{3}{c}{ Variabel } \\
\cline { 2 - 4 } & Berat Telur $(\mathrm{g})$ & $\begin{array}{c}\text { Berat Kuning Telur } \\
(\mathrm{g})\end{array}$ & $\begin{array}{c}\text { Massa Telur } \\
(\mathrm{g} / \text { /ekor/hari) }\end{array}$ \\
\hline R0 & 53,33 & 17,38 & 41,62 \\
R1 & 52,86 & 17,27 & 41,80 \\
R2 & 51,94 & 16,19 & 42,28 \\
R3 & 51,70 & 17,90 & 44,49 \\
\hline
\end{tabular}

Keterangan : Berbeda Tidak Nyata $\mathrm{P}>0,05$

Leeson dan Summer (1991) menyatakan bahwa berat kuning telur dipengaruhi oleh kualitas pakan. Hasil penelitian ini, berat kuning telur relatif sama. Artinya, kualitas ransum perlakuan dalam hal ini protein dan energi seimbang, sehingga menghasilkan berat kuning telur yang sama.

Pengaruh perlakuan yang tidak berbeda nyata terhadap berat kuning telur, pada penelitian ini penggunaan level 5-15\% tepung manure hasil degradasi larva lalat hitam (Hermetia illucens L.) terhadap berat kuning telur, kandungan zat-zat makanan dalam ransum terpenuhi.

\section{Pengaruh Perlakuan Terhadap Massa Telur.}

Data hasil penelitian menunjukkan bahwa pemberian tepung manure hasil degradasi larva lalat hitam (Hermetia Illucens L.) pada level 5\%-15\% tidak memberikan pengaruh yang nyata $(\mathrm{P}>0,05)$. Artinya penggunaan 5\%-15\% manure hasil degradasi larva lalat hitam dalam ransum relatif sama.

Rataan massa telur untuk masingmasing perlakuan berkisar antara 41,6244,49 g/ekor/hari. Hasil penelitian ini berada pada kisaran yang dikemukakan oleh Leke et al. (2016) bahwa rataan massa telur 40,10-44,94 g. Sehingga penelitian ini menunjukkan R3 memiliki massa telur paling tinggi yaitu 44,49 g. Rataan massa telur berkaitan dengan produksi telur. Konsumsi pakan yang tinggi akan menghasilkan produksi telur yang tinggi. Faktor yang menentukan massa telur adalah jumlah telur dan berat telur. Berat telur ada hubungannya dengan massa telur, dimana pola peningkatan massa telur sejalan dengan pola pertumbuhan folikel dewasa (kuning telur).

Massa telur dipengaruhi oleh konsumsi pakan, karena konsumsi pakan digunakan untuk pertumbuhan guna mencapai dewasa tubuh selain itu juga 
digunakan untuk produksi telur. Berat Kuning telur ayam buras berkorelasi positif dengan massa telur dan besar telur, tinggi rendahnya massa telur ini tergantung pakan (North dan Bell, 1990). Pada ransum perlakuan, semakin tinggi level penggunaan tepung manure hasil degradasi larva lalat hitam (Hermetia Illucens L.) diikuti dengan meningkatnya protein dan energi. Artinya, ada keseimbangan antara protein dan energi dalam ransum penelitian. Sehingga menghasilkan massa telur yang sama. Apabila massa telur meningkat maka produksi meningkat pula sebaliknya massa telur turun produksi telur menurun (Nasikin, 2015). Massa telur merupakan korelasi berat telur dan produksi telur.

\section{KESIMPULAN}

Berdasarkan hasil analisa data dan pembahasan bahwa pemanfaatan tepung manure hasil degradasi larva lalat hitam sampai level 15\% menghasilkan berat telur, berat kuning telur dan massa telur yang sama pada ayam kampung. MHD dapat digunakan dalam ransum ayam kampung sebanyak $15 \%$.

\section{DAFTAR PUSTAKA}

Hartono T. A., A.W. Puger, I.M. Nuriyasa. 2014. Kualitas telur lima ayam kampung yang memiliki bulu berbeda. Journal of Tropical Animal Science 2(2): 153-162.

Latifah, R. 2007. The increasing of afkir duck's egg quality with pregnant mare's serum gonadotropin (Pmsg) hormones. The Way To Increase Of Layer Duck. 4:1-8

Leeson, S and J. D. Summers. 2001. Comercial Poultry Nutrition. Thirth Edition. Departement of Animal and Poultry Science. University of Guelph Ontariom, Canada.

Leke, R., J. Laihad, F. Ratulangi. 2016. Effektivitas penggunaan Beta Karoten tepung tomat (Solanum Lycopersicum) implikasi dalam pakan terhadap kolesterol, lemak ,warna kuning telur dan serum metabolites ayam buras petelur. Hasil Penelitian. Fakultas Peternakan Universitas Sam Ratulangi Manado. Http://Repo.Unsrat.Ac.Id/1454/2/Je in_Rinny_Leke_HB_LAP_AKHI R_(NOV_201).Pdf

Manangkot, H. J. 2014. Black soldier fly larva manure degradation as fish meal replacer in native chicken ration. Seria Zootehnie 62:139-142.

Nasikin M., F.J. Nangoy, C.L.K. Sarajar, M.H.M. Kawatu. 2015. Pengaruh subtitusi sebagian ransum dengan tepung tomat (Solanum Lycopersicum L) terhadap berat telur, berat kuning telur dan massa telur ayam ras. Jurnal Zootek 35(2): $225-234$

North, M. O and D. D. Bell. 1990. Commercial Chicken Production Manual. The AVI Publishing Company, inc. New York.

Sarwono. 1995. Pengolahan Pengawetan Telur. Penebar Swadaya, Jakarta 
Scott, M.M., M. C. Nesheim and R. J. Young. 1982. Nutrition of The Chicken. M. L. Scott and Assiciate. Ithaca. New York.

Steel, R.G.D, and J.H Torrie, 1994. Prinsip dan Prosedur Statistika Suatu Pendidikan Giometrik, PT. Gramedia Pustaka Utama. Jakarta.

Tomberlin JK, Adler PH, Myers HM. 2009. Development of the Black Soldier
Fly (Diptera: Stratiomyidae) in relation to temperature. Jour Enviromental Entomol. 38:930934.

Umar M.M., S. Sundari, A.M. Fuah. 2000. Kualitas fisik telur ayam kampung segar di pasar tradisional, swalayan dan peternak di Kotamadya Bogor. Jurnal Med. Pet. 24(2).

Wangko S. 2014. Hermetia Illucens aspek forensik, kesehatan, dan ekonomi. Jurnal Biomedik 6(1): 23-29 